\title{
A PLACE FOR PRAGMATISM IN THE CURRENT EDUCATIONAL SYSTEM IN POLAND IN COMPARISON TO THE AMERICAN SYSTEM OF EDUCATION
}

\author{
Ewelina Czujko \\ ewelina.czujko@gmail.com \\ Adam Mickiewicz University, Poland
}

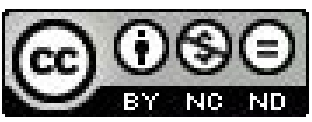

\begin{abstract}
Nowadays, when schools are closing and teachers are made redundant, a question arises whether the current educational system and the teaching methods or the knowledge and skills which people leave school with are adequate. Now, as never before, students and employers realize how important practical skills are in the labor market. Where are schools and universities in meeting this need? Do schools answer the natural needs people have for self-development? Does the educational system stimulate development of individuals interests? Unfortunately, I think the answer to a lot of these questions would be negative. Yet, if so, it is time we find a way to offer something more, not only to young people, but also to adults who want to explore the area of their interests by taking the trouble to obtain further degrees. One of the solutions to the urgent needs for the educational system is a pragmatic approach towards learning and teaching.
\end{abstract}

Key words: pragmatism, John Dewey, self-development, transmission, progressive schools.

\section{INTRODUCTION}

Pragmatism is an over-a-century-old and distinctively American philosophy. Nevertheless the whole knowledge of the founders of pragmatism had its source in influences from Europe, it was the boundless America that made a perfect place to develop pragmatic ideas. Geographical as well as social circumstances gave rise to the pragmatic approach towards America's formation. Yet, pragmatism is not only a philosophy but also, or perhaps primarily, it reflects the mentality of Americans. In the wild west, there was nothing else but quick and effective action that mattered. The people have become, who they are now, are as a result of persistent initiatives and work. In the endless nature of the New Land there was a lot to do. Thus, action became valued.

Pragmatism rose in opposition to dogmatic and orthodox philosophies such as neoheglism and transcendentalism, which did not respect human experience. Apparently, these philosophies contradicted the nature of constant action and lookout for its results. At that time, pragmatic thought was almost rebellious but reflected what the Americans needed. The necessity of building houses, schools and creating laws prevailed. Unrealistic ideas and thoughts disconnected from reality were not appreciated. 
Charles Peirce, in his essay How to Make Our Ideas Clear, was the one that formed the principles which gave the foundations for pragmatism. The pragmatic maxim is as follows: "Consider what effects, that might conceivably have practical bearings, we conceive the object of our conception to have. Then, our conception of these effects is the whole of our conception of the object" (Peirce, 1878, p. 293). So due to pragmatism, effects determine thoughts, truth and values; and thus, the presumed results influence the agent's action. Principally, Pierce considered himself as logician but he interacted and somehow made an impact on his scholar friend William James, who had major influence on John Dewey. Nowadays, the three personas are known as the founders of pragmatism. However they focused on different aspects of subject matter, the pragmatic maxim remains unchanged and it is vital for John Dewey's thought.

\section{METHODS}

Due to this in-depth introduction to American sources of mentality, we may derive the substantial needs in the American educational system now. Most of all, this paper will center around Dewey's philosophy of education with regard to the present circumstances in Poland compared to those in the United States. The philosopher was a founder of so-called progressive education, to which he gave existence at Chicago University at the end of the nineteenth century. Dewey was not only a philosopher and an academic educator but also an activist. He claimed "researchers need a setting that contains problems into which they can inquire. Dewey drew the conclusion that investigators of pedagogical questions needed a laboratory school which could test and exhibit in actual working conditions the results of the theoretical work" (Wirth, 1966, p. 42). As a consequence, he founded the Laboratory School in Chicago. There are according to Dewey several constituent elements, with which a progressive system of education should be incorporated.

First of all, continuity of all-important experience for a community is maintained due to renewal of the social group. "Each individual, each unit who is a carrier of the life-experience of his group in time passes away. Yet the life of the group passes on" (Dewey, 1963, p. 2). Furthermore, teaching and learning carries on thanks to communication, participation of individuals and transmission. "Society not only continues to exist by transmission, by communication, but it may fairly be said to exist in transmission and in communication" (Dewey, 1963, p. 4). As a result, people bounded by interaction pass on what they have in common supporting existence of its culture, knowledge and, in the end, community, nation or species. The significant contents they get from life-experience is not transmitted physically but through communication.

Consequently, the conclusions may be considered to be trivial, that is without interactive communication no social group can exist, no society's accomplishments can be transmitted from the older, experienced to the younger less experienced. For Dewey the school was a community. Yet, what is vital in this passage, and which seems to be neglected in the current situation of education in Poland, is cooperative development of teachers. Thus, once individuals become pedagogues they tend to forget about transmission of teaching experience among themselves in their local 
communities. Yet, how can teachers, of no matter what their nationality, develop? Transmission of the experience between educators would be the answer. Reflective observation is not alien to pedagogues. Evidently, there is some of this practice at the beginning of the teaching career. For instance, students preparing themselves for the role of educators observe an experienced teacher first. Then, they change position and the former takes place of the latter so, the experienced can pass on their opinion to the trainee about his work and, as a result contribute to his skills improvement. Usually, after practical training teachers are observed once a year, if they're lucky, by a superior and that would be it. Afterwards the interest of reflective peer observation declines. Self-development of educators often diminishes proportionally to their ageing career. From time to time, they take part in some training, symposiums, or congresses. Yet, it is not the same as collaborative development, where the teacher is to be observed by his pupils, who for a moment become the observer. The observer and the observed mutually share positive feedback about each other. They participate in an experience.

Secondly, the central idea of pragmatic education is experience. The experience is pedagogical. "Learning by doing" became a slogan associated with the pragmatic model of a school. People need to learn from their experience, so that the knowledge they gain can be useful and long-lasting. "Learning by doing, however, was not a phrase confined to the physical and manipulative probing of the young child. It meant being self-engaged in seeking understanding and control" (Wirth, 1966, p. 276). Progressive schools wanted to change the traditional environment of students' dull, laborious memorizing of a given educative content. The plan of Dewey was to make use of a natural interest the young have for the world. There is obviously "the difference in attitude of a spectator and of an agent or participant. The former is indifferent to what is going on [...]. The latter bound up with what is going on; its outcome makes difference to him" (Dewey, 1963, p. 124). There are two terms describing the participant's attitude; it is the concern that the agent shows and the interest. The problem is that the school curriculum is not related to the inherent and spontaneous activity of a child. As a consequence, it does not evoke the natural interest in a student. That is why the necessary educative contents which a pupils have to acquire need to be presented in a way that they engage the pupils and, as a result of its commitment, a student contributes to the society in return. Dewey believed the true interest of a student can have a dynamic power. Etymologically, the term interest, from Latin inter-esse, means something in between, it functions as connection between things that would otherwise remain distant (Dewey, 1963, p. 127). "Interest does not end simply in itself as bare feelings may, but always have some objective, end, or aim to which it attaches itself" (McDermott, 1973, p. 429). This interest-driven activity of an individual has a purpose of integration of school-based knowledge and everyday life experience.

Polish teachers would say that primary and secondary schools are equipped with tools which develop interest in students, namely after school clubs. Yet, the problem is that interest growth should not appear only in clubs and groups but the student's drive needs to be developed in the classroom during the regular lesson. Although the clubs are necessary for introducing some extra material for which there is no space in traditional curriculum such as drama/theater, robotics or team sport clubs. 
Dozens of schools in the United States which employ the John Dewey model focus on the individual progress of a student. But, it is important to note that exaggerated individualism was not the child's sentimentalism. "Dewey attacked as really stupid the sentimentalism of these child-centered progressives who, in his words, trusted plan lessness to liberate students' independent thinking. For Dewey, freedom is not the original state of human beings or the result of no discipline" (Russel, 1993, p. 187). Dewey understood freedom as environment, in which cooperation is designed by the experienced teacher and under his direction students acquire carefully selected and guided experiences. "Yet Dewey always insisted that method could not be divorced from content. The subject matter and the means of communicating it were inextricably bound together; and a successful performance depended on the mastery of both" (Handlin, 1959, p. 46). Nowadays, there are some methods and whole movements that draw on work of Dewey and may bring his thoughts into action.

First, the movement introduced by Dewey, which is problem-based learning. Students learn the educative material through the action of problem solving. "The values of Dewey's educational philosophy were patterned after those of communities of inquirers and productive workers. Methodologically, the rationale was inquiry-centered, with related emphasis on problem-solving, connection-seeing, relation-building" (Wirth, 1966, p. 277). As a result of such work, we receive flexible knowledge gained though teamwork where the "educator's task is to develop strategies that will lead students to see their work with new meanings - to reconstruct their experiences" (Wirth, 1966, p. 277). Apparently, due to this learning environment we observe a certain shift of responsibility. As a matter of fact, this approach strengthens the role of teacher, who becomes an instructor, or a tutor, but consequently, it empowers the student as well to active, cooperative, and resourceful learning. Moreover, in this method Dewey especially insisted that task based lessons were educative only if students saw their world with new meaning.

Recently, another learning and teaching strategy has become very popular in America. It is service learning, whose origins are derived from progressivism and pragmatism. Yet, it is not surprising that such an approach developed into an organized action because of the active contributions to the society Americans have in their blood. Thanks to this movement, students examine a real-life problem of a local community and they solve it in the classroom or outdoors, depending on the issue. For instance, if the problem of the local community is trash in a streambed, students provide a volunteer service by collecting the trash ${ }^{34}$. Then, they may examine the trash and on the basis of results of their findings they may propose some solutions to the emerging issue. Most of all, such work is not only some sort of a community service but also, in this example, students learn about water quality and laboratory analysis, they gain tangible knowledge about environmental pollution issues. In the meantime, pupils also practice problem-solving skills and improve communications about neighborhood communities.

Finally, the younger sister method of problem-based learning is a project based learning developed in late 1990s in the Buck Institute of Education. It is another way

34 National Service-Learning Clearinghouse, www. service learning.org, 20.01.2013 
of engaging students in thorough investigation, problem examination, and analysis. The aims are, therefore, similar to those in problem-based learning but the means of the undertaking and the number of people taking part may be different. "Within this framework, students pursue solutions to nontrivial problems by asking and refining questions, debating ideas, making predictions, designing plans and/or experiments, collecting and analyzing data, drawing conclusions, communicating their ideas and findings to others, asking new questions and creating artifacts" (Blumenfeld et al., 1991, p. 371). In Conclusion, these methods of learning and teaching are popular in America but, unfortunately, when it comes to Poland the contrary is true. Firstly, problem-based learning is, however, nothing new and teachers are often familiar with the approach. Yet, frankly speaking, the consequent implementation of the method hardly ever appears in schools. The second thing, which is service learning, is actually very rare and if there is any it is usually undertaken only occasionally. We cannot give a suitable example where all the elements of service learning are implemented. Charity and voluntary work is only just emerging in Poland. It is becoming more and more fashionable but is still not very common. In the end, project-based learning is probably the most common in Poland in comparison to the former types. Even so, it is not used in every subject in the school curriculum.

There is one more thing that differs between American and Polish schools. This is the function of guidance counselor. John Dewey emphasized it a hundred years ago that a child shows certain dispositions and predominant interest toward some knowledge and experiences and to others they remain indifferent. It is a role of the school to find out what is the child most interested in and the school should find a social function for him. "The child has his own instinct sand tendencies, but we do not know what these mean until we can translate them into their social equivalents. We must be able to carry them back into a social past and see them as the inheritance of previous race activities. We must also be able to project them into the future to see what their outcome and end will be" (Dewey, 1897, p. 80). Thus, in America, this important role has been taken mostly by the guidance counselor. Guidance is an umbrella encompassing many services aimed at students' personal and career development. "Career guidance and academic counseling can provide students with the necessary tools to set career goals, and give them an understanding of the education and skills they need to meet their goals" (Hughes \& Karp, 2004, p. 2). Americans pay a lot of attention to career development guidelines, which were lately emphasized in education due to the goals of No Child Left Behind legislation. So, the recent research on the effectiveness of career guidance and academic counseling provided many positive findings. "Researchers have found benefits to students of comprehensive guidance programs, career courses, academic counseling and computer-based guidance systems" (Hughes et al., 2004, p. 29). Students benefit from this program vocationally, academically as well as personally. In contrast, in Poland, some of the roles of a guidance counselor are taken by a school pedagogue. Yet, the attention given to this area is so little at Polish schools we cannot even compare it to the American extended system of guidance. Nevertheless looking at Polish students that leave universities and cannot find a satisfying job or cannot find work at all, put their degrees in question. Furthermore, another urgent issue is the ambition or wor- 
ry of their future students taking up two faculties or full-time work during studies which often results in dilettantism in both undertaken activities. Most of all, a lot of students even question the obtained degree or many of them disbelieve they may develop useful skills and competences, so they choose work over academic studies.

\section{CONCLUSION}

To summarize, pragmatism in America still plays an important role in the educational system. Even after over a hundred years, there are traces of this distinctively American thought in many primary schools, high schools and colleges, which employ the progressive model of education. Therefore, we may see pragmatic ideas in methodologies and strategies of learning and teaching in the organization of school and their actions. Furthermore, the pragmatic approach is a child-centered pedagogy, it develops the student broadly in many rewarding ways. And what is more, it contributes to society and, more importantly, to the local community. Moreover, this philosophy stresses experience gained knowledge, individualism, interest growth, and active learning. Pragmatism, however, assumes communication, transmission, and participation not only going down the line from teacher to student but in a community as a whole. Also, it appears along the line teacher to teacher through, for example, peer-observation. Finally, the school guides, instructs, develops and helps its students in their career paths so no student falls behind. Nowadays in Poland, as never before, we need to bring in some more pragmatic approach to learning and teaching in order to solve some urgent problems in Polish education.

\section{REFERENCES}

Blumenfeld, P. C., Soloway, E., Marx, R. W., Krajcik J. S., Guzidial, M., Palincsar, A. (1991). Motivating Project-Based Learning: Sustaining the Doing, Supporting the Learning. Educational Psychologist, 26 (3\&4), 369-398.

Dewey, J. (1963). Democracy and Education (2nd ed.). New York: The Macmillan Company.

Dewey, J. (1998). Experience and Education. Indianapolis: Kappa Delta Pi.

Dewey, J. (1897, January 16). My Pedagogic Creed. The School Journal, 3, (Vol. LIV), 77-80.

Dewey, J. (1956). The Child and the Curriculum. Chicago: University of Chicago Press.

Handlin, O. (1959). John Dewey's Challenge to Education: Historical Perspective on the Cultural Context. New York: Harper \& Brothers.

Hughes, K. L., Karp M. M. (2004). School-Based Career Development: A Synthesis of the Literature. New York: Columbia University, Institute on Education and the Economy.

McDermott, J. J. (1973). The Philosophy of John Dewey: The Lived Experience. (Vol. II), New York: G. P. Putnam's Sons.

Peirce, Ch. S. (1878, January). How to Make Our Ideas Clear?. Popular Science Monthly, 12, 286-302.

Russel, D. R. (1993). Vygotsky, Dewey, and Externalism: Beyond the Student/Discipline Dichotomy. Journal of Advanced Composition Ames, 13, 173-198.

National Service-Learning Clearinghouse. Retrieved January 20, 2013 from www. service learning.org.

Wirth, A. G. (1966). John Dewey as Educator: His Design for Work in Education (1894-1904). New York: John Willey \& Sons. 